\title{
Reseña del libro: Memorias del BIM: Biografías. Las víctimas de la Fuerza de Tareas 5 en La Plata, Berisso y Ensenada de Ana Julia Ramírez y Margarita Merbilhaá (editoras)' (2a ed. revisada y aumentada)
}

\author{
Laura Codaro \\ Universidad Nacional de La Plata, Argentina \\ lauritacodaro@hotmail.com
}

En el año 2015 salió a la luz el primer volumen de una serie de publicaciones en la que participan diferentes estudiantes, graduados y docentes de la Facultad de Humanidades y Ciencias de la Educación de la Universidad Nacional de La Plata, reunidos en el proyecto de investigación PPID: "La Plata, capital de la represión. El archivo de la DIPBA y la represión en La Plata, Berisso y Ensenada 1956-1976”. En aquel momento, hacía apenas un año que dicha unidad académica comenzaba a desarrollar sus actividades en el predio que pertenecía al Batallón de Infantería de Marina No3 -conocido como BIM 3-, donde durante la última dictadura cívico-militar funcionó un Centro Clandestino de Detención y Tortura y desde donde también fueron enviados soldados a la Guerra de Malvinas en 1982. Indudablemente, el hecho de dejar el edificio Tres Facultades construido en 1967 y ubicado en el corazón de la zona comercial de la ciudad de La Plata e instalarse en un campus universitario emplazado en las afueras -en sentido estricto, en la ciudad de Ensenada-, con características muy distintas, que ocupa un predio con una historia ciertamente traumática tuvo un gran impacto en la comunidad educativa que se manifestó de múltiples modos. Así surgió Memorias del BIM: Biografias. Las victimas de la Fuerza de Tareas 5 en La Plata, Berisso y Ensenada, un libro que no sólo intenta reconstruir la identidad y las historias de vida de las personas asesinadas y desparecidas por la Fuerza de Tareas No 5 (FT5) de la Armada que operaba en la zona, sino que también da cuenta del compromiso que la Universidad y sobre todo esta Facultad asumieron hace años por reconstruir la historia de la región y rescatar las memorias. En esta instancia interesa observar la segunda edición, revisada y aumentada, publicada en 2018 por un equipo de investigadores más amplio, que si bien conserva una estructura similar, aparece en un escenario político distinto, hay otro contexto de publicación donde surgen nuevos interrogantes y otros sentidos.

Para comenzar, el libro muestra en la tapa y la contratapa las cuatro fotografías escogidas para la primera edición, donde es posible reconocer las imágenes del predio del antiguo batallón y otras en las que se ven a los trabajadores fabriles de la zona, víctimas de la represión y la tortura de aquella época. En cuanto a la organización del volumen, luego de la ya conocida dedicatoria a José Panetteri, quien estuvo detenido en el BIM 3 y fue el primer decano de la FaHCE en democracia, y junto a él a otros compañeros y compañeras que padecieron a manos de la Fuerza de Tareas No 5 , se encuentra un índice que presenta: el prólogo a la segunda edición firmado por Ana Julia Ramírez, Margarita Merbilhaá y Lucía Abbattista; el prólogo a la primera edición que recupera las palabras del entonces decano de la Facultad, Aníbal Viguera, pronunciadas en el acto de recolocación de la placa de homenaje a los detenidos, desaparecidos y asesinados de la FaHCE, desarrollado el 24 de marzo de 2014; la Primera Parte que cuenta con una "Introducción" donde las autoras explican los objetivos y los alcances del libro y un apartado sobre la acción represiva de la Armada en la región, con una mención especial al rol del BIM 3 en el circuito de la FT5; la Segunda Parte titulada "Biografías" que reúne esta vez las historias de vida de 120 personas; un anexo documental incorporado en esta edición, que presenta las listas sindicales con los efectos represivos sobre sus integrantes, un cuadro con las cifras del 
impacto en la planta de trabajadores de Astilleros Río Santiago y el Frigorífico Swift, una solicitada de la coordinadora de Astilleros y Propulsora y dos registros periodísticos sobre las atrocidades cometidas en la región; finalmente, aparecen las referencias bibliográficas, el equipo de trabajo y los agradecimientos.

Entre estos apartados recientemente comentados, el prólogo a la segunda edición resulta iluminador para abordar y comprender este nuevo trabajo que se publica. Allí, inicialmente las investigadoras explican las dificultades que surgen al tratar de estudiar la historia reciente de nuestro país y particularmente al reconstruir las historias de vida de diversas personas asesinadas y desaparecidas, debido a que el Estado terrorista destruyó la documentación sobre su accionar represivo. Por ello, ante la ausencia de estas fuentes, otros materiales cobran aún más valor: los recuerdos de los familiares, amigos, compañeros y conocidos; los testimonios y la información que salen a la luz en el marco de los procesos judiciales; las investigaciones que se realizan en las universidades, en los centros de investigación y en otras instituciones culturales; los archivos, las bibliotecas, los museos y los sitios de memoria donde se acopian, se ordenan, se conservan y se divulgan los materiales y la documentación que se va recuperando. En efecto, estos son los principales caminos y recorridos que permitieron rectificar y ampliar datos de las 52 biografías que se publicaron en 2015 y posibilitaron la incorporación de 68 nuevas historias de vida, que dan un total de 120 biografías en este nuevo libro, que hablan del desafío por seguir conociendo más de cada uno y por reunir más nombres a la lista. Como destacan las autoras, en las últimas décadas las acciones impulsadas por el Estado durante la Presidencia de Cristina Fernández de Kirchner (2007-2015) fueron fundamentales para los procesos de conservación y sistematización de esta información. En consecuencia, las políticas estatales de promoción de los derechos humanos son esenciales para la realización de estas investigaciones y para la concreción de este tipo de trabajos. En este sentido, otra de las marcas distintivas de este segundo volumen es la denuncia que realizan las docentes, quienes manifiestan su gran preocupación -que es también la de sus compañeros y la de buena parte de las instituciones a las que representan- por las diversas medidas adoptadas por el gobierno actual que atentan contra la Memoria, la Verdad y la Justicia, algunas de ellas impactaron directamente en la producción del tomo ya que restringieron el acceso a documentación que antes era de uso público en las páginas oficiales. A esto se suman los discursos negacionistas y relativizadores de funcionarios del Estado en ámbitos institucionales y en los medios de comunicación masiva. Así, el hostil e incierto contexto político las conduce a preguntarse por la continuidad de las causas judiciales contra los crímenes de lesa humanidad, por la efectividad de las condenas a los perpetradores y por el porvenir de tantos espacios e instancias de reflexión y construcción memoria.

Por otro lado, este libro no puede ser leído y revisado sin mencionar que se enmarca en las múltiples iniciativas emprendidas por la Facultad de Humanidades y Ciencias de la Educación y la Universidad Nacional de La Plata en general, para recordar a los estudiantes, graduados y trabajadores de estas instituciones que fueron detenidos, desaparecidos y asesinados por el terrorismo de Estado. Aquí vale la pena nombrar el emotivo acto de homenaje y entrega de los legajos reparados de la FaHCE que se desarrolló el 27 de marzo de 2019, que dio cuenta de la ardua tarea realizada por el equipo de investigadores del proyecto acreditado que posibilitó el nacimiento de este libro, por la Comisión de Memoria, Recuerdo y Compromiso y la Prosecretaría de Derechos Humanos de la Facultad de Humanidades y Ciencias de la Educación. El hecho de conocer y dar a conocer al menos una parte de la historia de vida de las personas que estudiaron y/o trabajaron en la UNLP -porque el Programa de Memoria y Reparación Histórica contempla la restitución de legajos de otras unidades académicas-, de aquellos que se desempeñaban como obreros en fábricas de la región, que vivían a pocos metros del predio que hoy ocupa la FaHCE y que en muchos casos estuvieron detenidos en el BIM 3, significa reconstruir la historia tanto de la institución educativa como del espacio donde se estableció el campus universitario, del barrio que lo rodea, del accionar represivo de la Fuerza de Tareas $\mathrm{N}^{\circ} 5$ en la zona y de otros grupos que ejercieron el terrorismo de Estado durante los setenta y ochenta.

Por último y a modo de reflexión, la ampliación y la renovación de la publicación que se evidencia sobre todo en las nuevas 68 biografías incorporadas pero también en el anexo documental y en el incremento de 
las fuentes, muestra los esfuerzos que realiza la universidad pública para tender puentes entre el pasado y el presente ya que, como exponen las investigadoras, las vidas relatadas se entrecruzan de diversas maneras incluso en el presente, cuando sus familiares, amigos y compañeros conocen y comparten esos recorridos. Por ello, sus recuerdos conviven y resisten también en las páginas de este nuevo proyecto.

\section{Notas}

1 Ana Julia Ramírez y Margarita Merbilhaá (editoras) Memorias del BIM: Biografías. Las víctimas de la Fuerza de Tareas 5 en La Plata, Berisso y Ensenada (2 ${ }^{a}$ ed. revisada y aumentada). La Plata: Universidad Nacional de La Plata. Facultad de Humanidades y Ciencias de la Educación (Memorias del BIM; 2). Recuperado de https://libros.fahce.unlp.edu.ar/ index.php/libros/catalog/book/127 